\title{
Effects of Hay and Straw Mulches on the Establishment of Seeded Grasses and Legumes on Rangeland and a Coal Strip Mine
}

\author{
WILLIAM J. MCGINNIES
}

\section{Abstract}

Straw and grass-hay mulches at rates of 1,120 and $3,360 \mathrm{~kg} / \mathrm{ha}$ were applied to the surface after seeding or incorporated into the soil before seeding for 3 consecutive years of planting at Central Plains Experimental Range (CPER) near Nunn, Colorado, and at Colorado Yampa Coal Company mine (CYCC) near Steamboat Springs, Colorado. Averaged across 3 years, the stand ratings of Psathyrostachys juncea (Fisch.) Neveski, the only species seeded at CPER, were significantly better for the check (no mulch) treatment than for any mulch treatment. At CYCC, average stand ratings were significantly better than the check when $1,120 \mathrm{~kg} / \mathrm{ha}$ of straw mulch was applied to the surface after seeding. The species that consistently had the best stand ratings at CYCC were Astragalus cicer L., Bromus biebersteinii Roem and Schult., B. inermis Leyss., $B$. marginatus Nees, Elytrigia intermedia (Host) Nevski, E. intermedia subsp. barbulato (Schur) A. Löve, Medicago falcata L., $M$. sativa $L$., and Phleum pratense $L$. No erosion from the plots by either wind or water was observed regardless of mulch treatments.

Key Words: Psathyrosachys juncea, mulch, erosion, revegetation, reclamation

The Code of Federal Regulations addresses the subject of the use of mulches when surface mines are being revegetated by stating, "Mulch shall be used on all regraded and topsoiled areas to control erosion, to promote germination of seeds, and to increase the moisture retention of the soil." (U.S. Gov't 1985). In Montana, Darling and Young (1984) reported that native grass hay and straw mulches helped to control erosion, but that mulches did not improve the stands of seeded species. Smika (1983), in a study on the Great Plains in Colorado, found that a straw mulch reduced soil water loss and soil surface temperature. In California, straw was shown to be the most cost-effective mulch practice to retain soil on slopes in artificial rainfall tests (Kay 1983). Biggerstaff et al. (1984) reported that straw mulch increased infiltration and reduced sediment yield on reclaimed minelands in Kentucky.

Successful seedings have been made without the use of any mulch on both disturbed rangeland (Hull et al. 1958, McGinnics ct al. 1983) and topsoiled surface mined land (McGinnies and Nicholas 1980). On the basis of these successful seedings made without the use of mulch, the necessity of using mulches in reclaiming mined lands as required by the Federal Mined Land Reclamation Regulations became open to question. The study reported here was conducted to further evaluate the effectiveness of mulches for establishing seeded stands on disturbed rangelands and on strip mined lands.

\section{Methods}

This study was conducted to evaluate the effects of 2 rates of 2 different mulches applied to the surface or incorporated into the soil on subsequent establishment of forage grasses and legumes. Plantings were made for 3 consecutive years at 2 locations.

One area was located on the Central Plains Experimental Range (CPER) $31 \mathrm{~km}$ north of Nunn, Colo., at an elevation of $1,650 \mathrm{~m}$.

\footnotetext{
Author is range scientist, USDA-ARS, Crops Research Laboratory, Colorado State University, Fort Collins, Colorado 80523.

Published in cooperation with Colorado Agricultural Experiment Station, Fort Collins.

Manuscript accepted 7 August 1986.
}

Long-term average annual precipitation is $310 \mathrm{~mm}$, with $220 \mathrm{~mm}$ falling May through September. Soil was a Vona sandy loam, an Ustollic Haplargid. The area had been farmed, but was abandoned during the 1930's. Vegetation on the site at the time of this study was dominated by blue grama [Bouteloua gracilis (H.K.B.) Steud.], sedge (Carex heliophila Mack.), sand dropseed [Sporobolus cryptandrus (Torr.) Gray], and red threeawn (Aristida longiseta Steud.).

The other area was a coal strip mine operated by the Colorado Yampa Coal Company (CYCC) $32 \mathrm{~km}$ southwest of Steamboat Springs, Colo., at an elevation of $2,250 \mathrm{~m}$. Long-term average annual precipitation is $410 \mathrm{~mm}$. Topsoil (A and $B$ horizons) was stripped off before mining and then spread on the reshaped and smoothed spoil material after mining. Slopes ranged from 5 to 20\%. The spoils were from the Upper Cretaceous Mesa Verde group which consists of mixed beds of shale and sandstone. The spoils were a heterogeneous mixture of material from the various strata; mixing occurred during removal of the overburden by a dragline and by subsequent leveling of the spoil piles. Topsoil for the 1981 seeding came from an area where the pre-mining vegetation was aspen (Populus tremuloides Michx.). The aspen was shredded and mixed with the topsoil. The soil was from the SplitroWinevada complex. Topsoil for the 1982 and 1983 seedings came from areas where the pre-mining vegetation was dominated by big sagebrush (Artemisia tridentata Nutt.) and Gambel oak (Quercus gambelii Nutt.). Soil was a Routt loam, a fine montmorillonitic Typic Argiboroll.

Seedbed preparation at CPER consisted of moldboard plowing during the summer before seeding. Just before applying the treatments, the area was disked and smoothed. At CYCC, the topsoil was spread a short time before seeding. Just before seeding, a chisel-plow was used to relieve the compaction caused by the scrapers that spread the topsoil.

Table 1. Mulch treatments applied at CPER and CYCC.

\begin{tabular}{lcll}
\hline \hline Mulch & $\begin{array}{c}\text { Rate } \\
(\mathrm{kg} / \mathrm{ha})\end{array}$ & $\begin{array}{l}\text { Method of } \\
\text { application }\end{array}$ & $\begin{array}{l}\text { Abbreviated } \\
\text { treatment name }\end{array}$ \\
\hline Check & none & Surface & Check \\
Hay & 1120 & H-1-Su \\
Hay & 3360 & Surface & H-3-Su \\
Hay & 1120 & Incorporated & H-1-In \\
Hay & 3360 & Incorporated & H-3-In \\
Straw & 1120 & Surface & S-1-Su \\
Straw & 3360 & Surface & S-3-Su \\
Straw & 1120 & Incorporated & S-1-In \\
Straw & 3360 & Incorporated & S-3-In \\
\hline
\end{tabular}

'Applied to surface of soil after seeding.

2Incorporated into soil before seeding.

Mulch treatments (Table 1) consisted of grass hay from irrigated meadows or wheat straw (Triticum aestivum $\mathrm{L}$.) both applied at 1,120 or $3,360 \mathrm{~kg} / \mathrm{ha}$. Mulches were either incorporated into the soil with a vertical-axis rotary tiller before seeding, or were spread on the surface after seeding. All plots that did not have incorporated mulch were also cultivated with the rotary tiller at the time the mulch was incorporated, and all plots, both with incorporated mulch and otherwise, were cultipacked before seeding. Where 
mulch was spread on the surface, light-weight plastic netting was used to hold the mulch in place. Individual plots were 3.7 by $3.7 \mathrm{~m}$ at CPER and 5.5 by $5.5 \mathrm{~m}$ at CYCC. The experiment was a randomized complete block design with 4 replications at each location each year.

Seeding dates at CPER were 27 April 1981, 21 April 1982, and 28 April 1983. Russian wildrye [Psathyrostachys juncea (Fisch.) Nevski] var. 'Vinall' was planted with unit seeders to a depth of 2 $\mathrm{cm}$ at a rate of $100 \mathrm{seeds} / \mathrm{m}$ of row with a $30-\mathrm{cm}$ row spacing. Seeding dates at CYCC were 17 September 1981, 6 October 1982, and 14 September 1983. Seventeen to 18 species were planted in single rows with a single-row, hand-pushed seeder to a depth of 2 $\mathrm{cm}$ at a rate of 100 to 130 seeds/ $\mathrm{m}$ of row with a $30-\mathrm{cm}$ row spacing. (The species planted each year are listed in Table 4).

Stand ratings for each seeding were made at the end of the second growing season. Plantings are identified in text and tables by year of seeding. Ratings were based on the percentage of the seeded row that was fully occupied with seeded species $(0 \%=$ no plants, and $100 \%=$ a fully occupied row). Analysis of variance was used to analyze the data, and least significant differences (LSD) computed where appropriate.

\section{Results and Discussion}

\section{Central Plains Experimental Range}

May through June precipitation at CPER was 300, 420, and 240 $\mathrm{mm}$ for 1981,1982 , and 1983, respectively. Compared to the longterm average of $220 \mathrm{~mm}$, all 3 years were above average during the spring and summer growing season. The stand rating across all treatments averaged $62 \%$ in the 1981 seeding and $63 \%$ in the 1983 seeding, but was only $20 \%$ in the 1982 seeding (Table 2). 1982 was

Table 2. Effect of two rates of hay and straw mulches, incorporated into the soil or applied to the surface, on stand establishment ratings of Russian wildrye at CPER. Ratings are from second growing season after seeding.

\begin{tabular}{ccccccc}
\hline & & \multicolumn{4}{c}{ Year of seeding } \\
\cline { 4 - 6 } Treatment & & & 1981 & 1982 & 1983 & Mean \\
\cline { 4 - 6 } Check & & & $92^{3}$ & 35 & 65 & 64 \\
Hay & 11 & SU $^{2}$ & 75 & 20 & 58 & 51 \\
Hay & 3 & Su & 50 & 18 & 72 & 47 \\
Hay & 1 & In & 78 & 12 & 80 & 57 \\
Hay & 3 & In & 75 & 10 & 65 & 50 \\
Straw & 1 & Su & 65 & 25 & 62 & 51 \\
Straw & 3 & Su & 10 & 8 & 52 & 23 \\
Straw & 1 & In & 80 & 28 & 48 & 52 \\
Straw & 3 & In & 35 & 20 & 65 & 40 \\
LSD 0.06 & & & 22 & 15 & NS & 11 \\
\hline
\end{tabular}

1 1 $=1120 \mathrm{~kg} / \mathrm{ha}, 3=3360 \mathrm{~kg} / \mathrm{ha}$.

2SU = applied to surface after seeding, In = incorporated into soil before seeding.

$30 \%=$ no stand; $100 \%=$ row fully occupied by seeded species.

the wettest seeding year of the 3 , but for some reason had the poorest stands. In 1982, the seedbed was very dry and loose at the time of planting, and it is possible that the seed was planted too deeply. There was also a moderately dense volunteer stand of crested wheatgrass. [Agropyron desertorum (Fisch. ex Link) Schult.] from seed that blew in from an adjacent planting on the 1982 planting. The vigorous crested wheatgrass seedlings may have given the less vigorous seedlings of Russian wildrye strong competition.

In the 1981 seeding volunteer wheat plants were common in the $1,120 \mathrm{~kg} / \mathrm{ha}$ straw mulch treatments (S-1-Su and S-1-ln) and dense stands of volunteer wheat occurred in the $3,360 \mathrm{~kg} /$ ha treatments (S-3-Su and S-3-ln). Where there were dense stands of volunteer wheat, the grass stand was significantly reduced (Table 2). In 1981 and 1982 seedings, no mulch treatment resulted in higher stand ratings than the check. As with the straw mulch treatments in the
1981 seeding, the $3,360 \mathrm{~kg} /$ ha surface hay treatment (H-3-Su) resulted in significantly poorer stands of Russian wildrye than did the check treatment. No significant treatment differences occurred in the 1983 seeding. When the data for the 3 planting dates were combined, the check treatment produced significantly higher stand ratings than any of the mulch treatments except the $1,120 \mathrm{~kg} / \mathrm{ha}$ incorporated hay treatment ( $\mathrm{H}-\mathrm{l}-\mathrm{ln})$. No wind or water erosion was observed on any of the plots in this study.

Maximum and minimum soil temperatures were measured at a depth of $2.5 \mathrm{~cm}$ under 4 of the treatments from 29 April to $14 \mathrm{July}$ 1981. Maximum temperatures averaged 40.8, 42.2, 29.4, and $27.0^{\circ}$ $C$ and minimum temperatures averaged $13.6,14.0,16.8$, and $15.3^{\circ}$ $\mathrm{C}$ for the check, H-1-Su, H-3-Su, and S-3-Su treatments, respectively. Thus, the $3,360 \mathrm{~kg} / \mathrm{ha}$ rates of mulch applied to the surface lowered maximum temperatures and raised minimum temperatures. While there was an apparent relationship $(r=+0.95)$ between maximum temperature and stand rating, there is no evidence in this study to prove that the higher temperature per se resulted in higher stand ratings. Hart and Dean (1986) reported that days from seeding to emergence were controlled by soil temperature.

Soil moisture was determined gravimetrically on 18 dates between 2 May and 9 August 1983 for the surface $7.3 \mathrm{~cm}$. Average percent soil moisture was $9.7,10.4,10.8,10.4$, and 10.7 for the check, H-I-Su, H-3-Su, S-1-Su, and S-3-Su treatments, respectively. The mulches offered little, if any, benefit in terms of increased soil moisture content. On several occasions when samples were taken the day following a rainstorm, soil moisture was substantially higher under the $3,360 \mathrm{~kg}$ / ha mulches (14\% moisture) than in the check treatments (11\% moisture), but during periods between rainstorms, there was little or no increase in soil moisture under the mulches. It had been expected that mulches might substantially reduce soil moisture loss and produce better stand establishment. However, the slight increase in observed soil moisture was apparently either not sufficient to improve stand establishment, or any benefits that resulted from increased moisture may have been offset by the lower maximum temperatures under the mulch.

\section{Colorado Yampa Coal Company}

The 3 study sites on the CYCC mine were located adjacent to areas being actively mined, and thus were not in close proximity to each other. Because of these and because the topsoil originated from different sites, no attempt was made to combine the data from the 3 years of planting.

In the 1981 planting, volunteer wheat appeared in the straw mulch treatments, and the wheat formed a dense stand in the S-3-In treatment. Competition from the wheat reduced the seeded stand slightly (Table 3 ). The grass hay contained a large amount of

Table 3. Effect of two rates of hay and straw mulch, incorporated into the soil or applied to the surface, on stand ratings (average of all species) for three years of seeding at CYCC. Stand ratings are from the second growing season after seeding.

\begin{tabular}{cccccc}
\hline \hline & & & \multicolumn{3}{c}{ Year of Seeding } \\
\cline { 4 - 6 } Treatment & & & \multicolumn{3}{c}{ (stand rating, \%) } \\
Check & & & $40^{3}$ & 53 & 35 \\
Hay & $1^{1}$ & $\mathrm{Su}^{2}$ & 31 & 63 & 40 \\
Hay & 3 & $\mathrm{Su}$ & 24 & 61 & 35 \\
Hay & 1 & In & 27 & 51 & 40 \\
Hay & 3 & In & 22 & 54 & 28 \\
Straw & 1 & Su & 47 & 65 & 45 \\
Straw & 3 & Su & 41 & 62 & 42 \\
Straw & 1 & In & 36 & 58 & 29 \\
Straw & 3 & In & 33 & 52 & 35 \\
LSD 0.01 & & & 6 & 6 & 7 \\
\hline
\end{tabular}

$11=1120 \mathrm{~kg} / \mathrm{ha}, 3=3360 \mathrm{~kg} / \mathrm{ha}$.

2SU = applied to surface after seeding, IN = incorporated into soil before seeding $30 \%=$ no stand; $100 \%$ = row fully occupied by seeded species. 
smooth brome (Bromus inermis Leyss.) seed and a thick stand of smooth brome developed. The smooth brome competed strongly with the seeded species and caused a significant reduction in the seeded stand. Among the mulch treatments established in 1981, only the S-l-Su treatment produced significantly higher stand ratings than the check treatment.

No substantial volunteer stands of wheat or grass developed from the mulches applied in 1982 and 1983. In 1982, surfaceapplied mulches of both hay and straw significantly improved the seeded stands. In the 1983, seeding, the surface-applied straw mulches increased the stands of the seeded species, but surfaceapplied hay mulches did not. Incorporating the mulch into the soil had no effect on the seeded species in either the 1982 or 1983 plantings.

Stand ratings for most species varied greatly from year to year (Table 4). Ratings for some species, such as bluebunch wheatgrass

Table 4. Percent stand ratings at CYCC, average of all treatments, for three years of planting. 1

\begin{tabular}{lccc}
\hline \hline & \multicolumn{3}{c}{ Year of planting } \\
\cline { 2 - 5 } Species & 1981 & 1982 & 1983 \\
\hline Agropyron desertorum (Fisch. ex Link) Schult. & 43 & - & 15 \\
Astragalus cicer L. & 86 & 41 & 57 \\
ARS-1 hybrid2 & - & - & 55 \\
ARS-2 hybrid & - & - & 45 \\
Bromus biebersteinii Roem \& Schult. & 74 & 89 & - \\
Bromus inermis Leyss. & - & 68 & 47 \\
Bromus marginatus Nees & 49 & 78 & 65 \\
Elymus lanceolatus (Scribn. \& Smith)Gould & 1 & 52 & 2 \\
Elymus trachycaulus (Link)Gould ex Shinners & 34 & 79 & - \\
Elytrigia intermedia (Host)Nevski & 41 & 92 & 44 \\
Elytrigia intermedia subsp. barbulata (Schur) & & & \\
A. Löve & 53 & 79 & 62 \\
Elytrigia spicata (Pursh)D. R. Dewey & 2 & 19 & 0 \\
Festuca ovina L. & 19 & 45 & 19 \\
Festuca ovina duriuscula (L.)Koch. & 13 & 56 & 23 \\
Leymus cinereus (Scribn. \& Merr.)A. Löve & 1 & 26 & 0 \\
Medicago falcata L. & 61 & 67 & 48 \\
Medicago sativa L. & 58 & 45 & 40 \\
Phleum pratense L. & 65 & 93 & 93 \\
Psathyrostachys juncea (Fisch.)Nevski & 1 & 18 & 0 \\
LSD 01 & 10 & 15 & 11 \\
\hline Seed & & &
\end{tabular}

'Seeded in the fall. Ratings were made at the end of second full growing season. ${ }_{2}^{2}$ Hybrids of Elytrigia spicata (Pursh) D.R. Dewey $\times$ E. repens (L.) Nevski developed by Agricultural Reseach Service, USDA at Logan, Utah.

$30 \%=$ no stand; $100 \%=$ row fully occupied by seeded species. The dashed lines indicate no seeding was made that year.

[Elytrigia spicata (Pursh) D.R. Dewey], crested wheatgrass, and Russian wildrye, were consistently poor, while timothy (Phleum pratense L.) produced good stands for all years of seeding. Any species with a stand rating of $60 \%$ or higher was considered to have produced a "good" stand, and ratings between $30 \%$ and $59 \%$ were considered to be "fair." Ten of the species tested rated "fair" or better in all years they were tested. These species are intermediate wheatgrass [Elytrigia intermedia (Host) Nevski], pubescent wheatgrass [E. intermedia subsp. barbulato (Schur) A. Löve], slender wheatgrass [Elymus trachycaulus (Link) Gould ex Shinners], meadow brome (Bromus biebersteinii Roem and Schult.), smooth brome, mountain brome (B. marginatus Nees), cicer milkvetch (Astragalus cicer $\mathrm{L}$.), alfalfa (Medicago sativa $\mathrm{L}$.), sickle alfalfa (M. falcate L.), timothy, and hybrids ARS-1 and ARS-2 [Elytrigia spicata (Pursh) D.R. Dewey $\times E$. repens (L.) Nevski]. Of these species, slender wheatgrass, mountain brome and timothy are usually considered to be short-lived species on sites such as these (McGinnies et al. 1983).

Analysis of variance indicated a highly significant $(P<0.001)$ interaction between species and mulch treatments for all years of seeding. Cicer milkvetch, alfalfa and sickle alfalfa were generally better under a surface mulch. This may have been partially a result of the mulch and netting protecting the palatable seedlings from grazing by wildlife. Timothy produced good stands in all treatments. Sheep fescue (Festuca ovina $\mathrm{L}$.) and hard fescue [F. ovina duriuscula (L.) Koch.] tended to have better stands with a light mulch $(1,120 \mathrm{~kg} / \mathrm{ha})$ than with a heavy mulch or no mulch. Except for timothy and the 3 legumes, there was no consistent response among years.

One of the main reasons cited for using a mulch is to control wind and water erosion during the period of stand establishment (Slick and Curtis 1985). At CYCC, no erosion was noted that started within the study areas, so it was not possible to determine the effectivness of the various mulch treatments for erosion control. The primary methods of erosion control when reclaiming strip mined lands in northwest Colorado have been cultural practices such as contour furrowing. In the 1981 and 1983 seedings, overland water flow started outside the plot areas and flowed across some plot areas because of inadequate contour furrowing or poor ditching along the roads. In these cases, surface mulching reduced the cutting caused by the water that ran across the plots. Incorporated mulch had no observable effect in reducing erosion.

\section{Conclusions}

At CPER, surface mulchs slightly increased average soil moisture and possibly moderated soil temperatures, but the mulches did not improve establishment of the seeded Russian wildrye stands. At CYCC, the use of a light surface straw mulch significantly improved seeded stands, but at most, this improvement amounted to $12 \%$. An increase of this level may not justify the cost of the mulch and its application. However, in this study, all slopes were less than $20 \%$, and erosion was not a factor. In general, where erosion can be adequately controlled by contour furrows, the use of a mulch is probably not needed for satisfactory establishment of seeded species. On steeper slopes, a mulch might be considered as a possible supplement to the contour furrows for control of surface runoff and erosion. In those cases where the mulch material contained a large amount of seed, volunteer stands developed that competed excessively with the seeded species. If a mulch is used, the mulch material should be free of large numbers of seeds of unwanted species.

\section{Literature Cited}

Bigzerstafi, S.D., I.D. Moore, and R.C. Wamer. 1984. Effects of mulches on infiltration, runoff and erosion of reclaimed minelands. Reclamation News and Views, Vol. 2, No. 2. Coop. Extension Serv., Univ. of Kentucky, Lexington.

Darling, A.P., and S.A. Yount. 1984. The effects of native hay mulch on stabilization and native species establishment on mined lands in southeastern Montana. Proc. Montana Acad. Sci. 43:165-173.

Hart, R.M., and J.G. Dean. 1986. Forage establishment: weather effects on stubble vs. fallow and fall vs. spring seeding. J. Range Manage. 39:228-230.

Hull, A.C., Jr., D.F. Hervey, C.W. Doran, and W.J. McGinnies. 1958. Seeding Colorado Range Lands. Colorado Exp. Sta. Bull. 498-S. Colorado State Univ., Fort Collins.

Kay, B.L. 1983. Straw as an erosion control mulch. Agronomy Progress Report No. 140, Univ. of California, Davis.

McGinnies, W.J., and P.J. Nicholas. 1980. Effects of topsoil thickness and nitrogen fertilizer on the revegetation of coal mine spoils. J. Environ. Qual. 9:681-685.

MeGinnies, W.J., W.G. Hassell, and C.H. Wasser. 1983. A summary of range grass seeding trials in Colorado. Colorado State Univ. Special Series Pub. No. 21.

Slick, B.M., and W.R. Curtis. 1985. A guide for the use of organic materials in mulches in reclamation of coal minesoils in the eastern United States. USDA, Forest Service, Northeastern Station, Gen. Tech. Report NE-98.

Smika,D.E. 1983. Soil water change as related to wheat straw mulch on the soil surface. Soil Sci. Soc. Amer. J. 47:988-991.

U.S. Government. 1985. 30 Code of Federal Regulations 715.20(d). 